\title{
THE IMPACT OF INTERNATIONAL QUALITY STANDARD CERTIFICATION (IQSC) FOR ETHIOPIAN AND EGYPTIAN FIRMS' PARTICIPATION IN EXPORT MARKET
}

\author{
Md Shariful Islam \\ Student, Master in Economics (Major: International Trade), School of Economics, Shandong \\ University, Shandong Province, city: Jinan, China \\ Sartaj UI Islam \\ Student, Master in Economics(Major: International Trade), School of Economics, Shandong \\ University, Shandong Province, city: Jinan, China
}

Article DOI: https://doi.org/10.36713/epra5905

\begin{abstract}
Export is considered as the backbone of a country's economy. Export plays a vigorous role in the economic growth of a country. But a company's decision of becoming an export firm has certain constraints. This paper examines The International Quality Standard Certification (IQSC) and the firm's participation in the export market of Egypt and Ethiopia. By considering the volume, Egypt is one of the top exporters in Africa, while Ethiopia is considered an average exporter. We tend to find why some country's firms try to export more while others are less. Does the International Quality Standard Certification (IQSC) matter for firms' participation in the export market? How different are the characteristics of exporting firms in different countries? What other factors determine the firms' participation in the export market. We found that firms having IQSC export more than the firms that don't have IQSC and they have a comparative advantage. Due to economies of scale and higher efficiency, large firms have an advantage over small and medium firms on exporting to international markets. The firm's age is not an important factor for the probability to export. Productive, aged, foreign-owned and large firms usually export more than their counterparts.
\end{abstract}

KEY WORDS: IQSC (International Quality Standard Certificate), International Trade, Export Decision, Probit model analysis, IV regression.

\section{INTRODUCTION}

Exports have become major portions of international transactions of goods and services nowadays and happen to be a crucial component of a country's economy in generating required foreign exchanges that will be channeled to various components of gross output. At present, in the open market economy era, the export market is extremely and globally competitive. Economic theories proved that foreign market participation, especially export trade has a significant role in a trading nation's economic development. Over the past years, studies have been conducted to identify what explains international trade activities using aggregated macro data. Recently with the availability of micro (firm), data economists tried to see factors related to export decisions at the firm level.
However, firms from developing countries found it difficult to easily join international markets due to numerous interconnected issues sometimes depending on the trading partner's conditions and sometimes depending on domestic conditions. Challenges related to quality standards. lack of market research experience, inefficiency to meet quantity and quality requirements of buyers, difficulty with being flexible in line with growing consumer taste, market access issues bounded by trade negotiations, trans-border trade costs, domestic inefficiencies such as logistics and other infrastructural facilities, macroeconomic instabilities and many more can be mentioned as the bottlenecks on exporting firms in developing countries.

Over recent decades, the development, spread, and implementation of internationally accepted quality standards have gained increasing significance. 
The most widely diffused and adopted set of standards are those developed by the International Organization for Standardization (ISO), whose main objective is to harmonize standards worldwide to stimulate international trade and global welfare (Marimon, Casadesu 's, \& Heras, 2006). Yet, internationally, the adoption of certificates is still very unevenly distributed. In African and Latin American countries, for instance, adoption has been weak, but it has recently taken off and is growing rapidly. Asia and Eastern Europe are experiencing rapid increases.

Chen, Otsuki, \& Wilson (2006) also found that quality standards specifically testing procedures and lengthy inspection procedures by importers reduce firms (in developing countries) propensity to

Does the International Quality Standard Certification (IQSC) matter for firms' participation in the export market?

\section{LITERATURE REVIEW}

Before we begin our empirical investigation into the role of International Quality Standard Certification on a firm's participation in export, we briefly outline the existing literature on relevant fields. The literature includes global diffusion of certifications over time and geography, motivations and benefits for companies to become certified, and the role of certifications in international trade relations.

The impact of International Quality Standard Certification on a firm in participating in export participation has been the subject of recent research using macro data. Research done by Potoski and Prakash finds that ISO 9000 certification levels are associated with increases in countries' bilateral exports, particularly in the case of developing countries, which may be due to the relative severity of their quality assurance challenges (Potoski \& Prakash, 2009). In a similar study, Clougherty and Grajek find that ISO diffusion has no effect in developed nations but enhances exports from developing countries (Clougherty \& Grajek, 2008). The authors underscore the role of certificates as a substitute institution, reducing information asymmetries and transaction costs in developing countries with uncertain business environments.

This paper takes the analysis to the microlevel, the level at which certification should have its direct impact to validate and deepen this finding. Using firm-level data from the World Bank Enterprise Survey, we study the export engagement of firms from two African countries as Ethiopia and Egypt relation to firms' standards certification. About $90 \%$ of the firms are SMEs with fewer than 250 employees. The countries show varying levels of economic and institutional development but, compared to industrialized countries score medium to low on the World Bank Doing Business Index, export by a significant amount. Since every developing country has different economic structures and levels of export sophistication individual country analysis will provide a bit deeper in which later can be generalized to other developing countries. Cognizant of that we will focus on how International Quality Standard Certification (IQSC) influence firms' export market participation in the case of two African countries, one of them is Egypt which is one of the largest exporters among African countries and another country is Ethiopia which holds moderate status in terms of participation in the export market among fifty-five African countries.

\section{The Empirical Questions}

This study aims to investigate the following research questions

- How different are the characteristics of exporting firms in different countries?

- What other factors determine the firms' participation in the export market?

indicating the existence of important institutional voids in the countries of our sample.

We expect that the effect of IQSC will not only enable the firm to participate in international markets. It will also impact the volume of export, through the virtuous cycle it creates in helping firms penetrate more foreign markets and reach more buyers there. The effect is similar to the transaction cost-reducing the effect of trade liberalization and its impact on the export volumes of productive firms. The transaction cost reducing properties of Iis is important for all firms willing to operate in global markets, but we contend that they are especially important for firms based in countries where more severe institutional voids occur and essential institutions to support international transactions are lacking.

\section{METHODOLOGY}

Data: We used cross-sectional data from the World Bank's Enterprise survey data set for Ethiopia and Egypt for 2015 and 2016 respectively. This data set is found to be more appropriate to analyze a firm's export decision as it captures various important firm characteristics with a fairly representative sample (which is obtained by random sampling) including establishment years, size, employment, and ownership structure, productivity, sales, research and innovation activities, international quality standard ownership status among few.

Description of Variables and Model Specification: The variable of interest in this empirical study will be an international quality standard certification (IQSC). This variable will be captured by a binary variable which takes 1 if the firm owns the certificate and 0 otherwise. And based on previous studies other firm characteristics such as age, firm size, capital ownership, and productivity 
will also be added and their effect on the export decision will be assessed.

Table 1: Description of variables

\begin{tabular}{|c|c|c|}
\hline Variable & Description/ Measurement & Expected effect \\
\hline Export & $\begin{array}{l}\text { A firm is identified as an exporter if it has either } \\
\text { direct or indirect export or both. Will take } 1 \text { if the } \\
\text { firm has positive exports } 0 \text { otherwise }\end{array}$ & \\
\hline IQSC & $\begin{array}{l}1 \text { If the firm has international quality standards } \\
\text { certificate } 0 \text { otherwise }\end{array}$ & $\begin{array}{l}\text { Expected to increase the chances of } \\
\text { exporting }\end{array}$ \\
\hline Age & No years from the first year of operation & $\begin{array}{l}\text { Increasing or decreasing effect as } \\
\text { young firms might be energetic to } \\
\text { explore their opportunities on one } \\
\text { hand and old firms might have the } \\
\text { required experience in the foreign } \\
\text { market. }\end{array}$ \\
\hline $\begin{array}{l}\text { Capital } \\
\text { ownership }\end{array}$ & $\begin{array}{l}\text { This shows the capital ownership in the firm; foreign } \\
\text { or domestic. The firm is identified as domestic or } \\
\text { foreign-based on the } 50+1 \text { capital contribution. }\end{array}$ & $\begin{array}{l}\text { Foreign firms are expected to higher } \\
\text { probabilities of exporting }\end{array}$ \\
\hline Firm size & $\begin{array}{l}\text { Measured by the number of full-time permanent } \\
\text { employees. A firm is identified as small if the no of } \\
\text { employees is less than } 19 \text {, the medium between } 19 \\
\text { and } 100 \text {, and large if more than } 100 \text {. }\end{array}$ & $\begin{array}{l}\text { Large firms are expected to be more } \\
\text { likely to be exporters }\end{array}$ \\
\hline Productivity & $\begin{array}{l}\text { Measured by the ratio of total sales to full-time } \\
\text { permanent employees }\end{array}$ & $\begin{array}{l}\text { Firms with higher productivity are } \\
\text { expected to be exporters }\end{array}$ \\
\hline
\end{tabular}

Method of data analysis: For the empirical analysis since our dependent variable is binary, we can use limited dependent variable models to analyze firm characteristics that explain export market participation decisions. Linear probability (LPM), probit, and logit models can be fitted into our data. The Probit model will be employed in this study as the linear probability model has series of limitations in estimating probability (as it might produce negative or greater than one value for probability) and its linearity assumptions. Besides, the application of maximum likelihood estimator (MLE) in probit and logit models with random samples, generally produces consistent, asymptotically normal, and asymptotically efficient estimates (Wooldrigde, 2016). following that, the probit model in this study is specified as,

From the multiple linear regression model, we have $E X=\beta_{0}+\beta_{1} X_{i 1}+\cdots+\beta_{k} X_{i k}+\epsilon_{i}$

Where EX - refers to export status, $X$ refers to explanatory variables and $\beta$ refers to parameters to be estimated and $\epsilon$ refers to the error term. Having the value of EX as 0 and 1 and assuming the zeroconditional mean of, $\mathrm{E}\left(\epsilon_{i} \mid X_{i 1} \ldots \ldots X_{i k}=0\right)$ holds, $\mathrm{E}(E X \mid X)=\operatorname{Pr}(E X=1 \mid X)=\beta_{0}+\beta_{1} X_{i 1}+\cdots+$ $\beta_{k} X_{i k}$

where, $\operatorname{Pr}(E X=1 \mid X)$ is the response probability. Due to the limitations of LPM, we have to use nonlinear models that insure $\operatorname{Pr}(E X=1 \mid X)$ remains within the conventional probability values. thus,

$$
\operatorname{Pr}(E X=1 \mid X)=F\left(\beta_{0}+\beta_{1} X_{i 1}+\cdots+\beta_{k} X_{i k}\right)
$$

Where $\mathrm{F}$ is a function taking on values strictly between 0 and 1 . Considering $\mathrm{F}$ as a standard normal CDF the probit model is specified as,

$\operatorname{Pr}(E X=1 \mid X)=\Phi\left(\beta_{0}+\beta_{1} X_{i 1}+\cdots+\beta_{k} X_{i k}\right)$

The model to be estimated will be

EX

$=\beta_{0}+\beta_{1} I Q S C_{i}+\beta_{2}$ age $_{i}+\beta_{3}$ agesquared $_{i}$

$+\beta_{4}$ Inproductivity $_{i}+\beta_{5}$ domestic $_{i}$

$+\beta_{6}$ foreign $_{i}+\beta_{7}$ small $_{i}+\beta_{8}$ medium $_{i}$

$+\beta_{9} \operatorname{large} e_{i}+\epsilon_{i}$

The LPM and Logit estimations will be conducted to check the robustness of the probit estimation results.

The data set used in this study is collected from a representative sample through random sampling with high response ratios implying no problem of sampling bias and measuring errors. The inclusion of more relevant explanatory variables takes the treats that come from an omitted variable.

Descriptive analysis - Ethiopia: This subsection briefly presents summary statistics and discussions in a way that shows the characteristics of exporters against non-exporters 
Table 2: Summary Statistics

\begin{tabular}{|c|c|c|c|c|c|c|}
\hline Variables & Mean & SD & \multicolumn{2}{|c|}{ Mean values for two groups } & \multicolumn{2}{c|}{ Mean differences } \\
\hline Export & .103 & .304 & Exporters & Non-exporters & Difference & t-stat \\
\hline IQSC & 0.08 & .27 & .31 & 0.05 & $-.2565467^{* * *}$ & -8.1166 \\
\hline Age & 14.53 & 12.83 & 20.13 & 13.88 & $-6.241644^{* * *}$ & -4.0835 \\
\hline Age squared & 375.68 & 826.85 & 787.71 & 328 & & \\
\hline lnProd. & 12.41 & 1.48 & 13.23 & 12.3 & $-.9178971^{* * *}$ & -5.2313 \\
\hline Micro (<5) & .143 & .35 & .06 & .15 & & \\
\hline Small (5-20) & .399 & .49 & .19 & .42 & $.2284437^{* * *}$ & 3.9102 \\
\hline Medium (20-100 & .266 & .44 & .29 & .26 & -.0364062 & -0.6840 \\
\hline Large>100 & .191 & .393 & .44 & .16 & $-.2791143^{* * *}$ & -6.0333 \\
\hline Foreign & .0775 & .267 & .19 & 0.06 & $-.1307217^{* * *}$ & -4.1023 \\
\hline Domestic & .9197 & .271 & .79 & .93 & $.1422184^{* * *}$ & 4.4018 \\
\hline Gov't & .003 & .05 & .01 & .001 & & \\
\hline Total no. of firms & 748 & & 77 & 671 & & \\
\hline
\end{tabular}
$* * * \mathrm{p}<0.01$

After the preliminary data cleaning process from 848 observations, 748 were left. Accordingly, all the analysis is done on this final number of firms. As reported in the above table 10.3 percent of firms are found to be exporters while $8 \%$ have an international quality standard certificate. Average age and productivity were found to be 14 and a half years and 12.41, respectively. Looking at size distribution and capital ownership a large proportion of firms fall into the small and domestic category. After grouping the firms into exporter and non-exporter mean difference analysis was done. The results indicate that exporters have different characteristics from the non - exporters.
The statistically significant differences in mean values show that $31 \%$ of exporting firms have international quality standard certificate while its only $5 \%$ of the firms among the non-exporters. Comparison based on age, productivity, size, and capital ownership also found to align with previous conclusions: exporters are old, more productive, foreign-owned, and large.

Descriptive analysis - Egypt: This subsection briefly presents summary statistics and discussions in a way that shows the characteristics of exporters against non-exporters for Egyptian firms.

Table 3: Summary Statistics

\begin{tabular}{|c|c|c|c|c|c|c|}
\hline Variables & Mean & SD & \multicolumn{2}{|c|}{ Mean values for two groups } & \multicolumn{2}{c|}{ Mean differences } \\
\hline Export & .216 & .412 & Exporters & Non-exporters & Difference & t-stat \\
\hline IQSC & .278 & .448 & .702 & .161 & $-.5413005^{* * *}$ & -22.233 \\
\hline Age & 21.507 & 16.26 & 24.171 & 20.770 & $-3.400787^{* * *}$ & -3.3527 \\
\hline Age squared & 726.96 & 1174.1 & 880.23 & 684.577 & $-195.6617^{* *}$ & -2.6685 \\
\hline InProd. & 11.80 & 1.377 & 12.242 & 11.677 & $-.564377^{* * *}$ & -6.6375 \\
\hline Micro (<5) & .087 & .281 & .015 & .106 & $.0915328^{* * *}$ & 5.2325 \\
\hline Small (5-20) & .350 & .477 & .098 & .419 & $.3216878^{* * *}$ & 11.211 \\
\hline Medium (20-100 & .294 & .455 & .263 & .302 & .0389953 & 1.3673 \\
\hline Large>100 & .268 & .443 & .622 & .170 & $-.4522159^{* * *}$ & -17.9610 \\
\hline Foreign & .045 & .209 & .119 & .025 & $-.0941866^{* * *}$ & -7.3187 \\
\hline Domestic & .944 & .229 & .861 & .966 & $.1049579^{* * *}$ & 7.4348 \\
\hline Gov't & .009 & .099 & .018 & .007 & -.0107713 & -1.7334 \\
\hline Total no. of firms & 1,505 & & & & & \\
\hline
\end{tabular}

${ }^{* * *} \mathrm{p}<0.01,{ }^{* *} \mathrm{p}<0.05$

After the preliminary data cleaning process from 1,814 observations, 1,505 were left. Accordingly, all the analysis is done on this final number of firms. As reported in the above table-3, $21.6 \%$ percent of firms found to be exporters while 27.8 percent of firms have an international quality standard certificate. Average age and productivity were found to be 21 and half years and 11.8, respectively. Looking at size distribution and capital ownership a large proportion of firms fall into the small (35\%) and domestic (94.4\%) category. After grouping the firms into exporter and non-exporter mean difference analysis was conducted. The results indicate that exporters have different characteristics from the non - exporters. The statistically significant differences in mean values show that $70.2 \%$ of exporting firms have IQSC while only $16.1 \%$ of the firms among the nonexporters. Comparison based on age, productivity, 
size, and capital ownership also found to align with previous conclusions: exporters are old, a little more productive, foreign-owned, and large.

\section{Empirical Analysis - Ethiopia}

The data were fitted to the probit model specified above. The first model was estimated using IQSC as a regressor with the result reported below in the first column. The result shows that the estimated coefficient is statistically significant and positive implying that firms that own international quality standards are more likely to export. In the second regression we added other determinants of a firm's export decision that frequently found in firm export dynamics analysis for two reasons; to check if they can explain the export behavior in the least developed countries and to reduce problems related to omitted variables. the added regressors are age and age squared (suspecting nonlinear effect of age), productivity, capital ownership (categorized into three groups; domestic, foreign, and state-owned (reference category)) and firm size (micro (reference category), small, medium and large).

Table 4: Probit Model Estimation Results and Marginal Effects

\begin{tabular}{|c|c|c|c|}
\hline VARIABLES & (1) & (2) & $\begin{array}{l}\text { Delta-method } \\
\text { (Marginal effects) }\end{array}$ \\
\hline Iqs & $\begin{array}{l}1.154^{* * *} \\
(0.177)\end{array}$ & $\begin{array}{l}0.798^{* * *} \\
(0.223)\end{array}$ & $\begin{array}{r}.1115671^{* * *} \\
(.0323088\end{array}$ \\
\hline Age & & $\begin{array}{l}-0.0243^{*} \\
(0.0139)\end{array}$ & $\begin{array}{c}-.0033948^{*} \\
(.0019198)\end{array}$ \\
\hline agesquared & & $\begin{array}{l}0.000424^{* *} \\
(0.000190)\end{array}$ & $\begin{array}{l}.0000592^{* *} \\
(.0000263)\end{array}$ \\
\hline Lnpro & & $\begin{array}{l}0.187^{* * *} \\
(0.0504)\end{array}$ & $\begin{array}{l}.0261701^{* * *} \\
(.0070603)\end{array}$ \\
\hline Domestic & & $\begin{array}{l}0.184 \\
(0.755)\end{array}$ & $\begin{array}{l}.0257719 \\
(.10563)\end{array}$ \\
\hline Foreign & & $\begin{array}{l}0.706 \\
(0.779)\end{array}$ & $\begin{array}{l}.0986922 \\
(.1091188)\end{array}$ \\
\hline Small & & $\begin{array}{l}0.0695 \\
(0.249)\end{array}$ & $\begin{array}{l}.0097139 \\
(.0347692)\end{array}$ \\
\hline Medium & & $\begin{array}{l}0.309 \\
(0.255)\end{array}$ & $\begin{array}{l}0432315 \\
(.0353895)\end{array}$ \\
\hline Large & & $\begin{array}{l}0.535^{*} \\
(0.281)\end{array}$ & $\begin{array}{l}.0748243^{*} \\
(.0392057)\end{array}$ \\
\hline Constant & $\begin{array}{l}-1.425^{* * *} \\
(0.0704)\end{array}$ & $\begin{array}{l}-4.080^{* * *} \\
(1.023)\end{array}$ & \\
\hline $\begin{array}{l}\text { Observations } \\
\text { Pseudo R2 } \\
\text { \% correctly classified }\end{array}$ & $\begin{array}{l}748 \\
0.0822 \\
89.71 \% \\
\end{array}$ & $\begin{array}{l}747 \\
0.1657 \\
89.96 \% \\
\end{array}$ & \\
\hline
\end{tabular}

Robust standard errors in parentheses

$* * * \mathrm{p}<0.01,{ }^{* *} \mathrm{p}<0.05,{ }^{*} \mathrm{p}<0.1$

The estimation result using IQSC as the only regressor indicates that owning IQSC has a positive and significant effect firm's participation in the export market. Estimation of the probit model with more regressors also produces the same results regarding the effect of owning IQSC. Comparing the two results we observe a slight decrease in the magnitude of the coefficient of IQSC with a significant improvement in the overall fit (Pseudo $\mathrm{R}^{2}$ increased from .08 to .16) implying the importance of the additional regressors. The estimated coefficients on age, productivity, and size were found to be significant determinants of firms' participation in the export market in line with our prior expectations.

To identify by how much the likelihood of a firm to export changes in response to changes in the explanatory variables we estimated marginal effects (at means) as reported in the above table. And the result indicates that the probability of participating in the export market is $11 \%$ higher for a firm that owns IQSC than a firm with no IQSC. The statistically significant negative coefficient on age and the positive coefficient on age squared indicates that the effect of age is not linear i.e at younger age firms are less likely to engage in exporting and are more likely to export as age increase. The coefficient on productivity also aligned with our expectation implying firms with high productivity have higher probabilities to export compared to less productive ones approximately by 0.02 percent. the capital ownership variables were found to statistically insignificant. Looking at firm size estimates only the 
coefficient on large was found to be statistically significant which makes sense and supports the theory of economies of scale as it implies large firms have more chances of engaging in export. The marginal effect indicates that large firms are about $7 \%$ more likely to engage in export compared to micro firms.

Looking at the overall fit of the model the Pseudo $\mathrm{R}^{2}$ found to be 0.16 which is moderate given crosssectional data, and $90 \%$ of the predictions were identified correctly. Estimation from the logit and OLS models have also produced more or less comparable results (reported in the appendix).

Empirical Analysis - Egypt: The data was fitted to the probit model as specified in the methodology. The first model was estimated using IQSC as a regressor with the result reported below in the first column of table-5. The result shows that the estimated coefficient is statistically significant and positive implying that firms that own IQSC are more likely to export. In the second regression we added other determinants of a firm's export decision that frequently found in firm export dynamics analysis for two reasons; to check if they can explain the export behavior in the least developed countries and to reduce problems related to omitted variables. The added regressors are age and age squared (suspecting nonlinear effect of age), productivity, capital ownership (categorized into three groups; domestic, foreign, and state-owned (reference category)) and firm size (micro (reference category), small, medium and large).

Table 5: Probit model estimation results and marginal effects for Egyptian firms.

\begin{tabular}{|c|c|c|c|}
\hline VARIABLES & $\begin{array}{l}1) \\
\text { Probit }\end{array}$ & $\begin{array}{l}2) \\
\text { Probit }\end{array}$ & $\begin{array}{l}\text { Delta-method } \\
\text { (Marginal effects) }\end{array}$ \\
\hline Iqs & $\begin{array}{l}1.461^{* * *} \\
(.081)\end{array}$ & $\begin{array}{l}.994^{* * *} \\
(.093)\end{array}$ & $\begin{array}{l}.237^{* * *} \\
(.023)\end{array}$ \\
\hline Age & & $\begin{array}{l}-.002 \\
(.007)\end{array}$ & $\begin{array}{l}-.00061 \\
(.0017)\end{array}$ \\
\hline agesquared & & $\begin{array}{l}.00004 \\
(.00009)\end{array}$ & $\begin{array}{l}.00001 \\
(.00002)\end{array}$ \\
\hline Lnpro & & $\begin{array}{l}.071^{* *} \\
(.031)\end{array}$ & $\begin{array}{l}.017^{* *} \\
(.0076)\end{array}$ \\
\hline Domestic & & $\begin{array}{l}.018 \\
(.368)\end{array}$ & $\begin{array}{l}.0045 \\
(.0881)\end{array}$ \\
\hline Foreign & & $\begin{array}{l}.736^{*} \\
(.404)\end{array}$ & $\begin{array}{l}.1761^{*} \\
(.0969)\end{array}$ \\
\hline Small & & $\begin{array}{l}.130 \\
(.233)\end{array}$ & $\begin{array}{l}.0312 \\
(.0556)\end{array}$ \\
\hline Medium & & $\begin{array}{l}.614^{* * *} \\
(.228)\end{array}$ & $\begin{array}{l}.1471^{* * *} \\
(.0534)\end{array}$ \\
\hline Large & & $\begin{array}{l}1.112^{* * *} \\
(.229)\end{array}$ & $\begin{array}{l}.2660^{* * *} \\
(.0533)\end{array}$ \\
\hline Constant & $\begin{array}{l}-1.344^{* * *} \\
(.053)\end{array}$ & $\begin{array}{l}-2.689^{* * *} \\
(.575)\end{array}$ & \\
\hline $\begin{array}{l}\text { Observations } \\
\text { Pseudo R2 } \\
\text { \% correctly classified }\end{array}$ & $\begin{array}{l}1,501 \\
0.2175 \\
84.03 \%\end{array}$ & $\begin{array}{l}1,501 \\
0.2824 \\
84.28 \%\end{array}$ & 1,501 \\
\hline
\end{tabular}

Robust standard errors in parentheses

$* * * \mathrm{p}<0.01, * * \mathrm{p}<0.05, * \mathrm{p}<0.1$ 
The estimation result using IQSC as the only regressor indicates that owning IQSC has a positive and significant effect firm's participation in the export market. Estimation of the probit model with more regressors also produces the same results regarding the effect of owning IQSC. Comparing the two results, we observe a slight decrease in the magnitude of the coefficient of IQSC with a significant improvement in the overall fit (Pseudo $\mathrm{R}^{2}$ increased from 0.2175 to 0.2824 ) implying the importance of the additional regressors. The estimated coefficients on age, productivity, and size were found to be significant determinants of the firm's participation in the export market in line with our prior expectations.

To identify by how much the likelihood of a firm to export changes in response to changes in the explanatory variables we estimated marginal effects (at means) as reported in the above table. And the result indicates that the probability of participating in the export market is $23.7 \%$ higher for a firm that owns IQSC than a firm with no IQSC. The statistically significant negative coefficient on age and the positive coefficient on age squared indicates that the effect of age is not linear i.e at younger age firms are less likely to engage in exporting and are more likely to export as age increase. The coefficient on productivity also aligned with our expectation implying firms with high productivity have higher probabilities to export compared to less productive ones approximately by $1.7 \%$ percent. The capital ownership variables were also found statistically significant for a foreign firm, which is a foreign firm that has a $17.61 \%$ higher probability to export. Medium and large firms' coefficients are found statistically significant which makes sense and supports the theory of economies of scale as it implies large firms have more chances of engaging in export. The marginal effect indicates that large and medium firms are about $26.60 \%$ and $14.71 \%$ respectively more likely to engage in export compared to micro firms. Looking at the overall fit of the model the Pseudo $\mathrm{R}^{2}$ found to be 0.2824 which is moderate given cross-sectional data, and $84.28 \%$ of the predictions identified correctly. Estimation from the logit and OLS models have also produced more or less comparable results (reported in the appendix).

Analysis of IV Regression for Ethiopia and Egypt: Suspecting the problem of simultaneous causality between export decision and IQSC ownership as firms who are planning to join the export market might want to get quality certifications first, we have tried to employ IV regressions. Based on previous works of literature and the data set at hand we have identified one instrument for IQSC: whether or not the firm uses a foreign licensed technology. The explanation behind firms that use foreign licensed technology is urged by the license provider to operate in standardized frameworks and secure quality standard certificates.
Running the first stage regression which is specified as follows,

$$
\begin{aligned}
& \operatorname{pr}(I Q S C=1 \mid Z, W)=\quad \Phi(\beta 0 \quad+\gamma 1 Z 1 i \quad+\gamma 2 Z 2 i \\
& +\gamma 3 W 1 i \ldots+\gamma k W k i+v i
\end{aligned}
$$

Where $\mathrm{Zi}$ and $\mathrm{Wi}$ represent instruments and other exogenous variables in the structural model, using the data from Ethiopia we found the instrument as irrelevant with F - statistics of about 6.7. Similarly using the data from Egypt we found the instrument found to be relevant (F-statistics around 14) however the IV probit estimation with thousands of iterations failed to produce a meaningful result. Accordingly, we are unable to use it as an instrument and due to the limitation of our dataset, we couldn't apply IV estimation to check any change in the coefficients. Nonetheless, we can still use the results - which resemble results in previous studies - from the analysis to draw some conclusions regarding the effect of owning international quality standards ownership on a firm's export market participation.

Comparison of Regression Results and Descriptive Statistics: Ethiopia's market share in international trade is very poor which is only $0.52 \%$ and country rank is 30 th

among 55 African countries whereas Egypt's market share is moderately high which is $5.91 \%$ and country rank is 6th among 55 African countries (Workman, 2019). On average, $21.6 \%$ of Egyptian firms do export whereas only $10.3 \%$ of Ethiopian firms do export and $27.8 \%$ of Egyptian firms has IQSC whereas only $8 \%$

Ethiopian firms have IQSC. The average age of Egyptian firms (21.5\%) is significantly higher than Ethiopian firms (14.53 years). Surprisingly, the productivity of Ethiopian firms (12.41\%) is a little higher than that of

Egyptian firms (11.81). Among the Egyptian exporting firms, $62 \%$ are large whereas $44 \%$ of Ethiopian firms are large. For both countries govt. ownership firms are very few and most of the firms are domestic.

In the case of regression analysis, the repressors IQS, agesquared, Inproductivity, the large size of firms are significant at a $1 \%$ level of significance for both countries, and coefficients of all these regressors are positive whereas the coefficient of regressor "age" is negative. For Egyptian firms, regressor "age" is not statistically significant but significant for Ethiopian firms at $10 \%$ significance level. For Ethiopia, regressor's "foreign ownership and medium-sized firms" are not statistically significant but significant to export for Egyptian firms at 5\% and $10 \%$ significance level respectively. Regressors, small firms, and domestic ownership are not significant for both countries. Most of the case coefficients of regressors are larger for Egyptian firms than that of Ethiopian firms which denote a greater magnitude of the causal effect of significant regressors on the 
probability to export. All these comparative findings are supported by the OLS, Logit, and Probit regressions results which we attached in the appendix part of this term paper. Finally, for Ethiopia we found the instrument as irrelevant with $\mathrm{F}$ - statistics of about 6.7. Similarly using the data from Egypt we found the instrument found to be relevant (F-statistics around 14). However, the IV Probit estimation with thousands of iterations failed to produce a meaningful result.

\section{CONCLUSION}

Our study reveals that firms having IQSC export more than the firms that don't have IQSC and they have a comparative advantage. Some large firms have an advantage over small and medium firms on exporting to international markets due to economies of scale and higher efficiency. Government firm exports are not significant as they are focusing on local markets to meet the demand of local citizens. Most of the productive firms export more because of their production efficiency. But the ratio of productive firms is less and less significant. The age of the firm is significant for Ethiopian firms but not for Egyptian firms. So, age is not an important factor for the probability to export. Firms that export are

\section{REFERENCES}

1. Auriol, E., \& G.M. Schilizzi, S. (2015). Quality signaling through certification in developing countries. Journal of Development Economics, 105-121.

2. Blind, K., Mangelsdorf, A., \& Pohlisch, J. (2018). The effects of cooperation in accreditation on international trade: Empirical evidence on ISO 9000 certifications. International Journal of Production Economics, 50-59.

3. Chen, M., Otsuki, T., \& Wilson, J. (2006). Do Standards Matter for Export Success? World Bank Policy Research, WPS3809. World Bank Policy Research, WPS3809.

4. Clougherty, J., \& Grajek, M. (2008). The impact of ISO 9000 diffusion on trade and FDI: A new instrumental analysis. Journal of International Business Studies, 613-633.

5. Goedhuys, M., \& Sleuwaegen, L. (2013). International standards certification, institutional voids and exports from developing country firms. World Development, UNU-MERIT Working Papers.

6. Goedhuys, M., \& Sleuwaegen, L. (2016). International standards certification, institutional voids and exports from developing country firms. World Development, UNU-MERIT Working Papers.

7. Gumede, V., \& Rasmussen, V. (2002). Small Manufacturing Enterprise in South Africa: A Preliminary Assesment of Key Export Sucess Factors. Journal of Small Business and Enterprise Development, Volime 9(2), 162-171.

8. Jeffery M. Wooldridge, J. (2016). Introductory Econometrics: a modern approach. Cengage Learning, USA(6th ed). Marimon, F., usually more productive, aged, foreign-owned, and large. Looking at the overall fit of the model for Egyptian firms, the Pseudo R2 found to be 0.2824 which is moderate given cross-sectional data, and $84.28 \%$ of the predictions identified correctly. Estimation from the logit and OLS models have also produced more or less comparable results. On the other hand, the overall fit of the model for the Ethiopian data, the Pseudo R2 was found to be 0.16 which is moderate given cross-sectional data, and $90 \%$ of the predictions identified correctly. For Ethiopian firms, the capital ownership variables were found to statistically insignificant, and firm size estimates only the coefficient on large found to be statistically significant which makes sense and supports the theory of economies of scale as it implies large firms have more chances of engaging in export. The marginal effect indicates that large firms are about $7 \%$ more likely to engage in export compared to micro firms. Finally, using the data from Ethiopia we found the instrument as irrelevant with $F$ - statistics of about 6.7. Similarly using the data from Egypt we found the instrument found to be relevant (F-statistics around 14) however the IV Probit estimation with thousands of iterations failed to produce a meaningful result.

Casadesu's, M., \& Heras, I. (2006). ISO 9000 and ISO 14000 standards: An international diffusion model. International Journal of Operations and Production Management, 26,, 141-165.

9. Maskus, K., Otsuki, T., \& Wilson, J. (2005). The costs of complying with foreign product standards for firms in developing countries. World Bank foreign product standards for firms in developing countries. World Bank Policy Research Working Paper No. 3590.

10. Melitz, M. J. (2003). The Impact of Trade on Intra-Industry Reallocations and Aggregate Industry Productivity. Econometrica 71, 16951725.

11. Potoski, M., \& Prakash, A. (2009). Information asymmetries as trade barriers: ISO 9000 increases international commerce. Journal of Policy Analysis and Management, 28(2), 221-238.

12. Robert, M., \& Tybout, J. (1997). The Decision to Export in Colombia: An Empirical Model of Entry with Sunk Costs. American Economic Review, 545-564.

13. Roberts, M. J., \& Tybout, J. R. (1997). The Decision to Export in Colombia: An Empirical Model of Entry with Sunk Costs. American Economic Review, 545-564.

14. Sampaio, P., Saraiva, P., \& Guimaraes Rodrigues, A. (2009). ISO 9001 certification research: Questions, answers and approaches. International Journal of Quality and Reliability Management 26, 38-58.

15. Tybout, J. (2001). Plant-and Firm-Level Evidence on "New" Trade Theories. National Bureau of Economic Research, Working Paper No. -8418 . 
16. Tybout, J. (2001). Plant-and-Firm-Level Evidence on "New" Trade Theories. National Bureau of Economic Research, Working paper8418.

17. Vusi, G., \& VKamilla, R. (2002). Small manufacturing enterprises and exporting in South Africa: a preliminary assessment of key export success factors. Journal of Small Business and Enterprise Development, Vol. 9 No. 2, 162 171.

18. World Bank's Enterprise Survey Data. (2019, $\begin{array}{lll}\text { November 25). Retrieved from } & \text { 25 }\end{array}$ https://enterprisesurveys.org:

https://login.enterprisesurveys.org/content/sites/fi nanceandprivatesector/en/library.html 